\title{
Review article: Towards a context-driven research: a state-of-the-art review of resilience research on climate change
}

\author{
Ringo Ossewaarde ${ }^{1}$, Tatiana Filatova ${ }^{2}$, Yola Georgiadou ${ }^{3}$, Andreas Hartmann $^{4}$, Gül Özerol$^{2}$, Karin Pfeffer $^{3}$, \\ Peter Stegmaier ${ }^{5}$, Rene Torenvlied ${ }^{1}$, Mascha van der Voort ${ }^{6}$, Jord Warmink ${ }^{7}$, and Bas Borsje ${ }^{7}$ \\ ${ }^{1}$ Department of Public Administration, University of Twente, Enschede, Drienerlolaan 5, 7522NB Enschede, the Netherlands \\ ${ }^{2}$ Department of Governance and Technology for Sustainability, University of Twente, \\ Enschede, Drienerlolaan 5, 7522NB Enschede, the Netherlands \\ ${ }^{3}$ Department of Urban and Regional Planning and Geo-Information Management, University of Twente, \\ Enschede, Hengelosestraat 99, 7514AE Enschede, the Netherlands \\ ${ }^{4}$ Department of Construction Management and Engineering, University of Twente, \\ Enschede, Drienerlolaan 5, 7522NB Enschede, the Netherlands \\ ${ }^{5}$ Department of Science, Technology and Policy Studies, University of Twente, \\ Enschede, Drienerlolaan 5, 7522NB Enschede, the Netherlands \\ ${ }^{6}$ Department of Design Production and Management, University of Twente, \\ Enschede, Drienerlolaan 5, 7522NB Enschede, the Netherlands \\ ${ }^{7}$ Department of Water Engineering and Management, University of Twente, \\ Enschede, Drienerlolaan 5, 7522NB Enschede, the Netherlands
}

Correspondence: Ringo Ossewaarde (m.r.r.ossewaarde@utwente.nl)

Received: 23 March 2020 - Discussion started: 31 March 2020

Revised: 8 February 2021 - Accepted: 25 February 2021 - Published: 26 March 2021

\begin{abstract}
The twofold aim of this paper is to provide an overview of the current state of resilience research with regard to climate change in the social sciences and propose a research agenda. Resilience research among social scientists is characterized by much more diversity today than a few decades ago. Different definitions and understandings of resilience appear in publications during the last 10 years. Resilience research increasingly bears the mark of social constructivism, a relative newcomer compared to the more longstanding tradition of naturalism. There are also approaches that are indebted to both "naturalism" and "constructivism", which, of course, come in many varieties. Based on our overview of recent scholarship, which is far from being exhaustive, we have identified six research avenues that arguably deserve continued attention. They combine naturalist and constructivist insights and approaches so that human agency, reflexivity, and considerations of justice and equity are incorporated into systems thinking research or supplement such research. Ultimately, we believe that the overarching challenge for future research is to ensure that resilience to
\end{abstract}

climate change does not compromise sustainability and considerations of justice (including environmental, climate, and energy justice).

\section{Introduction}

A brief and non-exhaustive overview of resilience scholarship published in the period 1970-2020 reveals a diversification of research foci and themes, approaches and methods, and theoretical frameworks. Resilience has been a prevalent research topic among ecologists for several decades and, very soon after, among cyberneticists. Given the association of resilience with the natural sciences and engineering (see Indirli, 2019), it is perhaps not so surprising that most social scientists did not see the need to have recourse to the terminology or concept until much later. And if they did adopt the idea earlier, they were likely to embrace the naturalist theoretical framework that accompanied it (Holling, 1973, 2001; see Chandler, 2014). Other social scientists are still reluc- 
tant to accept resilience as a universal and unifying concept, pointing out the "core concepts and principles in resilience theory that create theoretical tensions and methodological barriers between the natural and social sciences" (Olsson, 2015). This conceived opposition between the natural sciences and social sciences may not be experienced by all naturalists or social scientists. Even more importantly perhaps, such opposition - real or surmised - may hinder fruitful collaborations in the face of our ecological crisis. Yet, collaboration, integration, or "transdisciplinarity" in the real worlds of universities and research institutes may not always reflect a genuine transcendence of disciplinary boundaries, but instead largely consist of natural sciences and engineering research in sustainability (Groß and Stauffacher, 2014). That said, there have been genuine attempts to transcend the limitations of both naturalism - in the strict, technical sense of the term (Andler, 2014) - and forms of social constructivism that border on relativism (Proctor, 1998a, b; Popa et al., 2015). Such transdisciplinary research is typically problem-oriented (Groß and Stauffacher, 2014).

Crawford Stanley Holling's ecological notion of resilience (Holling, 1973) is considered by some to be a bridge between the social sciences and engineering (Ostrom, 2007; Thorén, 2014). The appeal of Holling's socio-ecological system (SES) approach among some social scientists may be due to its being a corrective to the tendency of Holling's fellow ecologists to unconditionally embrace the methods and premises inherited from classical physics (see Holling, 1973; Thorén, 2014; Estêvãoet al., 2017; Davoudi, 2018). Holling corrected what he considered to be a flawed view of the world and of ecosystems, namely as closed or stable. Against the "equilibrium-centered" view, he emphasized the influence of random events (natural or human-caused) on ecological systems (Holling, 1973, p. 15). Yet, even this complex systems approach does not score very highly at the level of reflexivity, which is required to discover and "acknowledge overt or covert forms of dominance shaping public discourse and participation" (Popa et al., 2015). Slightly more positively framed, societal resilience to climate change also involves political and institutional factors, lifestyles and consumer habits, production patterns, and structures of power in general (see Douglas and Wildavsky, 1983; Blühdorn, 2013; Kolers, 2016; Fischer, 2017; Dryzek and Pickering, 2019). Resilience research that takes into account such social factors (which do not necessarily obey physical laws) can be broadly classified as belonging to "social constructivism".

The tsunami in 2004 and Katrina in 2005 seem to have acted as catalysts for generating more resilience research among social scientists (Pizzo, 2015). This increasing interest in resilience on the part of certain social scientists (and other scholars from different disciplines) cannot be detached from the popularity that the terminology started to gain among national governments and global governance actors, including the Rockefeller Foundation, for instance, at the beginning of the new century. Such tendency became stronger with the global financial crisis of 2007-2008. The widespread recourse to the language of resilience by powerful private and public actors has incited a series of scholarship critical of such discourse (Chandler, 2014; Pizzo, 2015; Lockie, 2016; Derickson, 2016). The latter, it is observed, easily hides vested political and economic interests and distracts attention from structural and institutional defects by emphasizing resilience through technological innovations. Katrina and, even more recently, Covid-19, it is argued, reveal a vulnerability that is not simply an unavoidable fragility in the face of natural hazards but is also the fruit of institutions and political decisions over a long period of time. Natural disasters tend to be perceived as indiscriminate and indifferent as to whom they affect. Yet, as Belkhir and Charlemaine (2007, p. 12) point out, "hurricanes may not single out victims by their race, or gender or class but neither do such disasters occur in historical, political, social, or economic vacuums". In other words, social, cultural, political, and economic conditions are conceived to be involved in the resilience or non-resilience of a nation or of particular groups to natural calamities (Henkel et al., 2006; Tierney, 2015; Lockie, 2016). In this regard, it is interesting to take note of the discussion surrounding the terminology "natural disaster" vs. "disaster" (Kelman, 2020).

The aim of this paper is to provide an overview of the current state of resilience research with regard to climate change in the social sciences and propose a research agenda. Resilience research among social scientists is characterized by much more diversity today than a few decades ago. Different definitions and understandings of resilience appear in publications over the last 10 years (see Indirli, 2019). Resilience research increasingly bears the mark of social constructivism, a relative newcomer compared to the more long-standing tradition of naturalism. Given this history, it is hardly surprising that social scientists focusing on resilience to climate change should initially have borrowed the research methods common to natural and applied sciences. "Social constructivist" approaches gradually made their entrance, especially in reaction to both the perceived inadequacy of particular naturalistic approaches and the increasing normative use of resilience in policy agendas (Weichselgartner and Kelman, 2015). There are also approaches that are indebted to both "naturalism" and "constructivism" (which, of course, come in many varieties). "Ecological naturalism", for instance, departing from ecological science, integrates constructivist insights about power and mastery, the diversity of human knowledge, and the politics of knowledge. It thereby resists the reductionistic tendencies of positivist empiricism (Code, 2005). "Critical realism" (Carolan, 2005) similarly wishes to avoid the danger of reductionism while profiting from the wealth of (applied) natural sciences.

Hence, though we acknowledge the many varieties of both naturalism and constructivism and the various endeavors to transcend the limitations of both naturalism and constructivism, we observe that most resilience research in the social 
sciences still takes place in the dialectical field constituted by these two approaches, in their strict, traditional senses (see Andler, 2014). This is the theme of the next section. But first we briefly examine how resilience research in the social sciences has undergone a thorough diversification. Such diversity, however, sometimes means that research takes place in parallel worlds and that there is little cross-fertilization between scholars. It is suggested that social scientific inquiry into resilience in the context of climate change could be raised to the next level if these two different approaches meet and interact. To this end, we reconstruct contemporary debates in that particular field of studies and distill recurrent research topics that divide social scientists. The issues of adaption and transformation in the context of severe disturbances or shocks that come with climate change (such as hurricanes, floods, droughts, and heat waves) appear to be such divisive topics. Finally, naturalist and constructivist directions, as well as possible cross-fertilizations of these two currents, for future resilience research are identified. We point out that future resilience research in the social sciences - that is, the types of questions raised, theoretical frameworks, and modes of analysis - will also be determined by changing conditions (ecological, political, and socioeconomic).

\section{The diversification of resilience research in the social sciences}

One of the earliest appearances of the term resilience - in European literature at least - seems to have been in one of Aesop's fables, namely The Oak Tree and the Reeds. According to one of the versions of the story, the oak tree becomes uprooted during a storm while its fellow reeds survive it. In a conversation, the oak tree expresses its bewilderment that the fragile reeds were able to resist such a mighty storm while it succumbed. The reeds reply that it is precisely their nonresistance that saved them. Through their capacity to bend, they moved with the direction of the wind (which thus did not break them) and rose again when the storm was gone. They were flexible enough. The reeds "bounce" back and are thus "resilient". Indeed, the English word "resilience" derives from the Latin resilire, which generally meant rebounding. This Latin word can be found in the writings of Seneca the Elder, Pliny the Elder, Ovid, Cicero, and Livy; to rebound is also the sense in which resilire is used by Cicero in his Orations (Alexander, 2013). The term also appears in Lucretius On the Nature of Things, where it denotes "being forced back by a resisting surface [...] with reference to the action on Nature" (Pizzo, 2015). Along this line, nature compels all things to "spring off".

Despite the various meanings attributed to the term, the connotation attached to resilire was commonly that of rebounding (see Indirli, 2019). Up to the early nineteenth century, this was the predominant understanding of resilience in common language and imagination. A slight shift appeared when engineers started to use the term to refer to the properties and capacities of materials to absorb tensions and release energy and recover their original forms, without breaking or disfiguration after undergoing some external shock or disturbance (such as extreme weather conditions; Estêvão et al., 2017; Bergström, 2018; Davoudi, 2018). In the 1950s, psychologists re-adapted the common sense of the term to mental health and used it to study the coping mechanisms of concentration camp survivors. Later, the concept is used to study various kinds of trauma, misfortune, adversity, stress, and mental recovery (Bourbeau, 2015; Estêvão et al., 2017; Bergström, 2018; Schwartz, 2018). In the 1970s, the ecologist Crawford Stanley Holling (Holling, 1973, p. 14) redefines resilience as "a measure of the persistence of systems and their ability to absorb change and disturbance." Thus understood, resilience is widely conceived as the opposite of vulnerability, which is defined as the inability to absorb change and disturbance (Gallopin, 2006; Miller et al., 2010). For instance, a coastal system that is vulnerable to accelerated sea-level rise is not resilient enough (Smit et al., 1998). In such accounts, greater resilience means becoming less vulnerable to change and shocks. That said, a system can still be vulnerable to other changes while being resilient in other respects (Gallopin, 2006). Holling incorporates resilience in a socio-ecological system (SES) approach to analyze the stability and strength of ecological systems, which are constituted by the interaction between natural ecosystems and human societies (Alexander, 2013; Bergström, 2018; Béné et al., 2018; Hoekstra et al., 2018). Ecosystems, as noted earlier, are rarely closed systems but are instead subjected to natural and human influences.

In the social sciences, resilience research has been influenced by these earlier studies. As a result, some social scientists have recourse to mathematical and simulation models and consider resilience to be a property of a system, which can be (made) weak or strong. In these studies, society is modeled as a social system that consists of parts (including agents and technologies) and physical properties that can be objectively studied (Aiken, 2006; Floridi, 2017). Resilience as a system property is an objective measure of the dynamic equilibrium, stability, strength, or survivability of a socioecological system, including coastal systems, urban systems, forest systems, etc. (Hoekstra et al., 2018). Such approaches, indebted to applied natural sciences and the complex systems theory, can be very useful, especially when both the problem and the solution are primarily and solely of a technical nature. That said, even an apparently purely technical process such as water purification involves reckoning with various social factors (for instance, changing habits, medicine uses, and particular surroundings of water collection systems).

The story becomes even more complicated when, for instance, attempts to make communities more resilient to climate change overlook the political and cultural reasons why particular groups living in particular areas are more vulnerable to the effects of climate change (such as heavy rainfall, 
droughts, and heat waves). These problems may not even get sufficient attention due to, for instance, "cultural racism and "institutional racism" (Henkel et al., 2006, p. 102). Social constructivism provides social scientists with the conceptual and analytical tools to understand social realities. Historically, constructivism in the social sciences arose in reaction to what was experienced as the narrowness of the naturalist approach (once again, in the technical/strict sense of the term, according to which "the social is part of nature, social processes are natural processes, with causal powers reducible to natural causation" (Andler, 2014, p. 286)). Most social constructivists do not believe that reality is objective in the naturalist sense (strictly defined) and thus cannot be fully grasped. Instead, it is conceived that natural and social phenomena can only be understood by taking into account diverse factors that determine and influence human perceptions, experiences, meanings, interests, values, identities, patterns of domination, etc.

In resilience research, social constructivists typically model society as a historically embedded construct that is the result of particular understandings of nature, society, and the person, values, symbols, and historical practices (which may not be very rational or just), and power relations. These social scientists tend to be more sensitive to the potential and actual abuse of power. When engaging with resilience issues in the context of climate change, they typically express concern for vulnerable communities. Research topics can thus include the (un)equal distribution of environmental burdens, struggles for recognition, claims to participation, and unequal impacts of anthropogenic climate change (Braun, 2014; Yanarella and Levine, 2014; Skillington, 2015; Sjöstedt, 2015; Weichselgartner and Kelman, 2015; Pizzo, 2015; Lockie, 2016; Derickson, 2016; Lyster, 2017; Schlosberg et al., 2017; Mummery and Mummery, 2019). Davoudi (2018, p. 5), for instance, problematize the very notion of "resilience", pointing out that there are "unjust resilience building programs" that not only neglect disadvantaged communities, but also create "resilient enclaves" for "privileged elites". Similarly, Glaser et al. (2018, p. 3) observe that resilience can be "wicked" when an undesirable status quo is being maintained. Reflexivity is arguably an indispensable part of resilience research (see Popa et al., 2015).

\section{The dialectic between naturalism and constructivism}

Social scientists focusing on resilience to climate change have inherited an enormous body of scholarship on resilience stemming from the physical sciences and engineering, cybernetics, evolutionary biology, and psychology, among others. In the 1970s, social scientists could thus have recourse to both closed-systems theories and complexity theory to think about resilience to climate change (Dahlberg, 2015; Davoudi, 2018). Some of them also merged the two models so that socio-ecological systems became conceptualized as adaptive complex systems (Wiese, 2016; Bergström, 2018). Holling's
SES is an example of the integration of complexity theory in ecological science. According to the adaptive complex system line of thought, the resilience of a system depends on the capacity of individual agents to cope with uncertainty and complexity. They are able to interact and self-organize, learn, and adapt (in an incremental or transformative way), thereby making the system flexible enough to absorb shocks and develop even in the face of drastic changes (Jesse et al., 2019).

Social scientists drawing on complexity theory and evolution-based models tend to emphasize a type of laissezfaireism, pointing out that adaptive complex systems have their own self-organizational structures that should not be interfered with (Adger et al., 2011). Bureaucratic interventions to address vulnerability and increase resilience to climate change are said to generate unintended consequences that may well reduce a system's ability to absorb changes and disturbances. In 2001, Holling introduced the notion of "panarchy" as an alternative to hierarchy, to safeguard the self-organization of complex systems against the threat of bureaucratic intervention (Holling, 2001). Derived from the ancient Greek god of the woods, Pan, panarchy refers to the structure in which complex (ecological and social) systems are interlinked in an evolutionary process of adaptive cycles of growth, accumulation, restructuring, and renewal (Berkes and Ross, 2016). Accordingly, when confronted with shocks (like extreme weather events), adaptive systems stabilize with supporting self-organizing structures until those structures are overstretched and can no longer absorb changes and disturbances; this is when there is a transformation of the system (Allen et al., 2014). Resilience is therefore conceived as a primary system property that is measured by the magnitude of shocks that can be absorbed before the structures of system change (Boyer, 2020).

Some social scientists show a predilection for agent-based modeling $(\mathrm{ABM})$ as their mode of analysis in resilience research (see Cote and Nightingale, 2012; Pumpuni-Lenss et al., 2017; Patriarca et al., 2018; Mirchandani, 2020). They therefore aim at the constant refinement of simulation tools that can integrate complexity, uncertainty, and multiplicity of agents and techniques of regulation in favor of adaptation. Since the 1970s, when it emerged from mathematical sociology, ABM has been used in theoretic complexity research for analyzing complex systems (Conte and Paolucci, 2014). $\mathrm{ABM}$ is a computational mode of analysis that simulates complex (non-linear) systems that include diverse agents that make decisions, interact, and learn or adapt in their everchanging environment, according to programmable rules (Hawes and Reed, 2006; Farmer and Foley, 2009; Martin and Schlüter, 2015; Sun et al., 2019). ABM computes, in probabilistic terms, the recovery process of complex (non-linear) systems under stress and tracks the emergence of new stages, phases, or entries into new adaptive cycles (Filatova et al., 2016). Resilience to climate change, as a system property, can thus be calculated (Pumpuni-Lenss et al., 2017). Since ABM traces feedbacks between micro- and macroscale ex- 
plicitly, it also enables scholars to estimate the resilience of a system's individual agents, communities, or (sub)groups of agents.

The above approaches to resilience rely on what can be broadly defined as "natural" sciences and their applied variants. Society and humans are conceived according to the theories and models common in these disciplines. The application of conceptual frameworks and models developed to study allegedly objective and objectifiable things to the interaction between humans and their social and natural environments is not without its challenges and dangers. Scientists, including social scientists, may unwittingly serve political agendas if they are oblivious of their own political and ideological commitments. The blurry line between science and politics is illustrated by Holling's and Friedrich Hayek's reappropriation of complexity theory to criticize government interventions (Walker and Cooper, 2011; Davoudi, 2018). The historical context of both men, namely, one marked by Keynesian policies, should arguably also be borne in mind. One of the possible (side) effects of scientific models presuming resilient individual agents is that they can lend credence to the idea of self-reliant and self-sufficient individuals and further the "neoliberal individualization of responsibility" (Davoudi, 2018, p. 5). Such alliance, perhaps unwitting, between political agendas and science is the great fear of those social constructivists whose primary commitment is to justice and the protection of vulnerable individuals and groups (Fainstein, 2014; Derickson, 2016; Kolers, 2016; Lockie, 2016; Lyster, 2017; Mummery and Mummery, 2019).

One of the major points of contention between naturalism, in the strict sense, and social constructivism is that most social constructivists are unwilling to conceive resilience to climate change as a system property (an intellectual attitude that does not imply that all naturalistic approaches actually conceive resilience as a system property; see Andler, 2014). Instead, resilience is perceived as a socio-political construct created by diverse stakeholders (Walsh-Dilley and Wolford, 2015; Weichselgartner and Kelman, 2015; Kythreotis and Bristow, 2017). This means that it is not a neutral or technical element and, accordingly, requires constant critical scrutiny to uncover its possible ideological and mythical nature (Alexander, 2013; Bourbeau, 2015; Boas and Rothe, 2016; Juncos, 2018; Wessel, 2019). Some scholars have pointed out the neoliberal ideology underpinning both theories/models and policies that rely on the idea of adaptive cycles governed by invisible laws, which make intervention undesirable (Chandler, 2014; Tierney, 2015). It is thereby overlooked that the so-called self-organizing system is itself the result of political decisions over a long period of time. Governments are thus accused of shifting the responsibility for vulnerable systems (which are themselves the products of formal and informal institutions and political decisions, among other things), floods, pollution, safety, welfare, health, etc., onto resilient individuals or individuals who ought to become more resilient, which is another word for self-reliant (Braun, 2014; Pizzo, 2015; Tierney, 2015; Howell, 2015; Anderson, 2015; Ksenia et al., 2016; Schwartz, 2018; Davoudi, 2018). In some cases, such resilience discourse enables governments to avoid their public responsibility. An instance of such wicked dynamics is governments shifting the responsibility for the provision of access to water onto local "communities" while the latter might be absent due to strife or inadequate management capacities (Katomero and Georgiadou, 2018). In such situations, vulnerable individuals and groups are denied this basic human right, while other powerful groups claim sole access to water.

Social constructivists are generally critical of the very language of resilience. Those who point out the discursive or narrative nature of resilience-based political speeches and policies are usually indebted to Michel Foucault's idea of a discourse. The latter refers to systems of thoughts and beliefs expressed through language and practices that systematically construct subjects and societies of which they speak. In other words, both language and practices are creative acts. Through resilience discourses, a particular type of subject (like resilient or self-reliant) and a particular type of society (like a market-based "society") are discursively constructed and reinforced (Miller et al., 2010). Evans and Reid (2013) thus argue that resilience has the character of a doctrine, according to which the resilient subject must accept and constantly adapt to a dangerous and changing world. Given this doctrine, vulnerability is rejected as weakness or a moral flaw, which is very much like a lack of character or willpower (Cole, 2016). A problematic normativity is brought into existence when citizens are expected to adapt to ecological and societal catastrophes by becoming self-reliant (Fainstein, 2014; Tierney, 2015; Kolers, 2016; Ribault, 2019). In other words, some (or most) social constructivists do not merely try to answer the question of how to make societies and individuals resilient to climate change but instead question the normativity of the concept resilience. Such a critical approach is arguably problematic and counterproductive in some cases. The urgency of real problems (like rising sea levels that threaten millions of people) makes a dialogue between different approaches highly desirable.

\section{Bridging the naturalist and constructivist view on resilience}

Given the different appraisals of the very concept of resilience with respect to climate change among social scientists, it has been widely questioned whether resilience can possibly operate as a theoretical model or a unifying paradigm - and whether such a unifying paradigm would be desirable in the first place (Alexander, 2013; Thorén, 2014; Bourbeau, 2015; Fainstein, 2015; Pizzo, 2015). The question of whether such a unifying paradigm is possible or desirable need not be answered here. It can still be argued that it is 
desirable to bring together the insights gained from naturalistic and constructivist approaches to enrich and renew understandings of resilience to climate change. Climate change resilience research that relies on naturalist and naturalistic premises may be able to provide quick solutions to crises precisely because various unpredictable and apparently irrelevant elements are discounted. The focus on the obvious problem without taking into account the broader context which may be problematic - has many advantages, certainly if the bigger picture is taken into account after recovery from an acute crisis. In the event of a flood, for instance, the first concerns should arguably be evacuation and preventing another flood. Once everyone is safe, the question as to why the flood has affected a particular group can be raised. The particular choices made with regard to urban and rural planning can be critically scrutinized. Answers to the various questions that a flood and its aftermath raise will require knowledge from many disciplines. Resilience to floods will mean much more than building dams. It will also involve criticism of particular social structures, institutions, and decisions that have rendered some people or areas more vulnerable to natural hazards or the effects of climate change.

\subsection{The debate on adaptive and transformative resilience}

Resilience research in recent years reveals divergence among social scientists when it comes to the issue of adaptation and transformation (Chandler, 2014; Redman, 2014; Fainstein, 2014; Dahlberg et al., 2015; Sjöstedt, 2015; Boas and Rothe, 2016; Duit, 2016; Ziervogel et al., 2016; Clément and Rivera, 2017; Lyster, 2017; Schlosberg, Collins and Niemeyer, 2017; Fazey et al., 2018; Glaser et al., 2018; Hoekstra et al., 2018; Jesse et al., 2019; Dryzek and Pickering, 2019). Such disagreement can partly be explained by a particular ambiguity in Holling's SES approach (Redman, 2014). In the 1970s, Holling (1973) reinterpreted resilience as bouncing back or forward in terms of SES adaptation. Adaptation refers, on the one hand, to the capacity of agents to influence the system (and influence or strengthen resilience as a system property). And on the other hand, it alludes to panarchical adaptation to new (ecological and social) environments, as an evolutionary process towards a new stage, phase, or adaptation cycle (Boyd et al., 2015).

Yet, as Holling emphasizes, the bouncing back and bouncing forward of a system does not only refer to a return to some previous (dynamic) equilibrium or to the persistence and endurance of systems. It also refers to socioecological transformation in an ongoing process of nonequilibrium and instability and reinvention of systems in changing environments marked by different adaptive cycles, such as growth, accumulation, restructuring, and renewal (Folke, 2006). Transformation means that agents are capable of creating a new system and a new discourse, particularly when the existing system is untenable or illegitimate. This focus on undesirable status quos and hence on transformation - after a crisis, for example - is characteristic of many social constructivists but may also be important to those who have somehow combined the goods of several worlds (Carolan, 2005; Code, 2005). Scholars critical of resilience discourses propounded by national and international governance actors, therefore, do not try to find ways to increase resilience, but above all things, they try to ignite new imaginations and counter-discourses necessary for realizing less unsustainable futures (Fazey et al., 2018). Recently, a middle ground between adaptation and transformation has been developed, in the form of "transformational adaptation" (Pelling et al., 2015; Mummery and Mummery, 2019). Examples of transformational adaptations include green growth or the greening of present economies. These are changes that are aligned with the scale of projected, possible, and desirable changes within systems that are informed by considerations of justice.

Resilience research that emphasizes system adaption to climate change focuses on the degree to which complex systems can build capacity for learning, as a way to respond to shocks or disturbances, embrace evolutionary change, and live with complexity and uncertainty (Thorén, 2014; Juncos, 2017; Warmink et al., 2017; Béné et al., 2018). Given unpredictability and uncontrollability, adaptive resilience is especially a matter of short-term planning, uncertainty reductions, and incremental and path-dependent changes (Borsje et al., 2011; Haasnoot et al., 2013). Adaptive resilience the system's re-stabilizer - is conceived as inherently positive, while disturbances and shocks (destabilizers) are negative (Duit, 2016; Lockie, 2016). Research building on the premise that adaptive resilience is desirable thus partners well with climate risk management (Boyd et al., 2015; Berbés-Blázquez et al., 2017). The response of the Dutch government to the overflowing of the Meuse River in 1993 and 1995 illustrates research-based risk reduction through adaption that involves a break with the past. The Dutch government did not simply have recourse to build more dykes and strengthening existing barriers, which has been the traditional approach, but instead opted for river deepening and widening measures (Dijkman et al., 1997; Hamers et al., 2015). Since its completion in 2015, the Room for the River project has been considered effective thus far, particularly as its secondary objective to increase ecosystem values in the river appears to be successful. However, research completed in 2013 (Ward et al., 2013) points out that the risk of flooding in certain parts of the Netherlands is expected to increase in the future (2- to 3 -fold increase by 2030 compared to 2010) and emphasizes the need for change with respect to land use. Indeed, the researchers found that the impact of land use on flood risk is likely to be greater than climate change itself. This means that households, for instance, can help to reduce the risk of future floods through a change of behavior. But that is easier said than done. The authors of the report note that there are few means to move Dutch households to participate in such risk reduction and point out the need for further 
research on ways to implement new measures and motivate people to change their behavior (Ward et al., 2013, p. 45).

Research that prioritizes transformative resilience in the context of climate change looks at a system's internal capacities, capabilities, and relations that enable it to create a new condition marked by new or different power relationships and different priorities. In such cases, constructivists typically point out the undesirability and injustice of status quos (Ziervogel et al., 2016; Rothe, 2017; Béné et al., 2018). According to this perspective, "anthropological shocks" (Beck, 2015 , p. 80) open up new horizons, reassessments (including of past ideas, beliefs, and practices), and rediscoveries (Fazey et al., 2018). Anthropological shocks refer to the disruptive and lasting effects of certain horrendous events on people. There is no going back to how it was before these shocks. According to these critical voices, adaptive resilience research and policies based on that research contribute to maintaining systems that are unjust (Skillington, 2015; Derickson, 2016; Fazey et al., 2018; Mummery and Mummery, 2019). This does not mean that adaptive resilience research - which usually draws on naturalistic methods - does not include justice in its models (Redman, 2014; Thorén, 2014; Ksenia et al., 2016; Schlosberg et al., 2017; Bergström, 2018). Yet, such models are based on, and reflect, existing systems. They do not take structures of power into account (Howell, 2015; Pizzo, 2015; Lockie, 2016; Derickson, 2016; Davoudi, 2018). This also means that they cannot possibly integrate thoroughly unequal power relationships - such as the Global North-Global South relationship - into their models (Pizzo, 2015; Clément and Rivera, 2017; Davoudi, 2018; Glaser et al., 2018; Dryzek and Pickering, 2019).

The limitations of models need not be a problem unless they become the political tools to implement adaptive measures (Fainstein, 2014; Weichselgartner and Kelman, 2015; Huang et al., 2016; McGreavy, 2016; Ziervogel et al., 2016; Ribault, 2019). Adaptive responses to shocks and disturbances may blur long-term sustainability visions and enable powerful stakeholders to maintain their positions (Lockie, 2016; Derickson, 2016; Rothe, 2017; Estêvão et al., 2017; Ribault, 2019). Kythreotis and Bristow (2017) call this phenomenon the "resilience trap" - the reinforcement of established power relations and contemporary resilience discourses (Blühdorn, 2013; Redman, 2014; Yanarella and Levine, 2014; Lockie, 2016; VanderPlaat, 2016; Schilling et al., 2018; Glaser et al., 2018; Ribault, 2019). Hence, some constructivist scholars reject Holling's panarchy concept, emphasizing that transformation towards more sustainable worlds is not an evolutionary process of adaptive cycles but a political-administrative phenomenon (see Boyer, 2020).

\subsection{Transformative resilience and sustainability}

For some constructivist scholars, genuine sustainability presupposes transformative resilience because inherently unsustainable systems cannot be made more wholesome by tweak- ing a few of their constituents. In cases of inherent or structural defects, resilience refers to the capacity to "use" a crisis to critically reappraise the social, cultural, and political choices underpinning SES and, if necessary, to make new choices (Pizzo, 2015; Weichselgartner and Kelman, 2015; VanderPlaat, 2016; Ziervogel et al., 2016; Hughes, 2017; Jesse et al., 2019). The reconfigurations of SES do require interventions by all governance actors. Transformative resilience used in this sense is thus a post-neoliberal concept. When applied to the energy transition, transformative resilience entails a more radical change than adaptive resilience does. In the former case, this means concrete plans to phase out fossil fuels and hence to reorganize economies, where the old fossil fuel industry no longer holds the reins (Alexander and Yacoumis, 2018; Stegemann and Ossewaarde, 2018; Bergmann and Ossewaarde, 2020). Adaptive resilience is involved when the phasing out of fossil fuels is being delayed and when certain discourses ensure that the fossil fuel industry is given carte blanche to carry on business as usual (Buschmann and Oels, 2019). Geels (2014, p. 24) explains how "the coal regime has so far resisted climate change pressures through a 'clean coal' discourse and the innovation promise of carbon capture and storage (CCS)".

It is widely agreed that non-renewable fossil energy sources like coal, oil, and gas are largely responsible for landscape degradation, air and water pollution, and greenhouse gas emissions that have been causing global warming (Cook et al., 2016). The sustainable energy transformation, accordingly, is, amongst other things, a response to climate change. In a more robust sense, it is more than simply a response to climate change. Instead, the latter is a symptom of the inherent unsustainability of the present socioeconomic system and is therefore an additional, urgent reason to radically transform the latter (Alexander and Yacoumis, 2018). Hence, those who conceive an energy transition as an adaptive necessity are primarily concerned with what several scholars call "energy resilience" (Béné et al., 2018, p. 120; Jesse et al., 2019 , p. 21), that is, with the continuing supply of energy to support the prevailing socioeconomic system and prevention of power outage during the transition. In other words, reliable energy supplies at stable costs must be kept going to support the present socioeconomic system (Wiese, 2016). Since system collapse is to be avoided at any cost, adaptive resilience to climate change means incremental changes and the increasing use of renewables without stopping the use of fossil fuels (Berbés-Blázquez et al., 2017; Schilling et al., 2018; Stegemann and Ossewaarde, 2018). Adaptive resilience here means the gradual greening of energy and hence the gradual greening of the system through green technological innovation without essentially changing the old system (Geels, 2014). In fact, important stakeholders of the "old regime" resist the transition to a new order. Such resistance takes, among other things, the form of continuing investments in fossil-fuel-based energy and greening measures - which create the impression of a transition (especially in the media) - 
thereby further anchoring the existing system (Alova, 2020; Gençsü et al., 2020). The incentives to "destabilize" such a flourishing economic system are thus weakened.

Scholars who challenge existing social structures therefore critically point out that the primary and sole focus on energy resilience (that is to say, energy security) is more likely to maintain the energy system's status quo, which further allows powerful stakeholders to promote fossil energy and keep their established positions. As Simpson (2013, p. 249) notes, the

critical approach to energy security challenges the existing economic, political and technical assumptions that underpin traditional debates on energy production and consumption, but it also challenges traditional notions of security that have the nationstate as their referent object.

An uncritical adaptive energy resilience approach can thus reinforce "energy injustice", that is, the "the unequal distribution of ills" throughout the energy system, whereby that system is defined as "the entire energy chain, from mining, conversion, production, transmission, and distribution, right through to energy consumption and waste" (Jenkins et al., 2016, p. 179). Scholars who focus on the transformative resilience of energy systems are therefore generally committed to energy justice and have a more critical approach to energy resilience (or security) because the latter presumes the socioeconomic order and unequal structures of power (Jenkins et al., 2016; Heffron and McCauley, 2017). They propose the creation of a renewable-energy-based system, energy commons, and collaboratives beyond the energy establishment (VanderPlaat, 2016; Bourbeau and Ryan, 2018; Juncos, 2018; Schwartz, 2018; Acosta et al., 2018; Jesse et al., 2019).

\section{Six emerging themes in diversified resilience research}

Current research on resilience to climate change in the social sciences reflects a diversity of focuses and commitments, ranging from climate-resilient infrastructure to issues of justice and power. Some critical scholars question the very notion of resilience and point to the wicked dynamics involved as resilience becomes a policy instrument to consolidate one particular, often established social reality at the expense of other, fairer possible alternatives. Research that unwittingly supports such political purpose has thus attracted the criticism of scholars who emphasize transformation towards new social constellations, where power (to influence the course of things), responsibility, burdens, and benefits are fairly distributed (Derickson, 2016; Jenkins et al., 2016; Heffron and McCauley, 2017; Alexander and Yacoumis, 2018; Davoudi, 2018; Glaser et al., 2018; Stegemann and Ossewaarde, 2018). Ultimately, the overarching challenge for future research is to ensure that resilience to climate change does not compro- mise sustainability and considerations of justice (including, environmental, climate, and energy justice). Based on our overview of recent scholarship, which cannot possibly be exhaustive, we have identified six research avenues that deserve continued attention.

One of them is the further development of transdisciplinarity, which includes the collaboration between constructivist and naturalistic approaches to resilience, not only at the institutional level, but especially also at the level of research itself. Such transdisciplinarity thus means that a scholar draws on different scientific traditions to approach one particular problem. In other words, transdisciplinarity does not restrict itself to "forced" collaboration between scholars from different disciplines, which is a prevalent organization of inter-, multi-, and transdisciplinarity (see Pohl, 2001). It also does not mean homogenization of science and the repression of the diversity of human thinking. It entails an appreciation of diverse scientific vocabularies, of the variety of scientific knowledge, and the acknowledgement of clashes, which can be conducive to the advancement of human knowledge (see Pfeffer and Georgiadou, 2019). Bringing together various perspectives of a complex reality arguably fosters our understanding of that same reality.

There have been several attempts to "bridge" the disciplinary divide, some more successful than others. Such attempts at integration are deemed even more desirable when it comes to environmental issues (Pompe and Rinehart, 2002; Mooney et al., 2013). Edward O. Wilson's famous "consilience" is a good example of a failed attempt since he takes the natural sciences and their methods to be hegemonic. Wilson (1998, p. 11) thus notes

Given that human action comprises events of physical causation, why should the social sciences and humanities be impervious to consilience with the natural sciences? [...] Nothing fundamental separates the course of human history from the course of physical history, whether in the stars or in organic diversity.

Similarly, the allegedly transdisciplinary "Earth system analysis" approach, developed at the Potsdam Institute for Climate Impact Research (Germany), makes use of mathematical modeling in which the world is conceived as a cybernetic organism (Pohl, 2001, p. 40).

More successful integrative approaches do not allow the methodology and theoretical framework of one particular scientific tradition to dominate the other. We have mentioned ecological naturalism above as an example of such an approach. The critical realist (Proctor, 1998a, b) is yet another way to benefit from the realism of the naturalist approach, thereby avoiding relativism, without falling into the trap of reification and determinism. With regard to energy, for instance, Jenkins et al. (2016, p. 179) argue that a "combination of the social science account of energy (policy) with its natural science counterpart (systems)" helps us to determine 
where injustices lie, even more accurately than through social constructivist approaches alone. Conversely, evolutionary resilience approaches that draw on systems thinking can be enriched by taking into account human agency, the issue "unequal power relations that can disrupt feedback loops and channels of communications" (Davoudi, 2018, p. 4), and more generally, the idea that we cannot simply wait for evolutionary change, or for systems to explode, but instead have to realize alternatives through human imagination.

This brings us to the second theme, which could be dubbed "critical resilience" research. Critical thinking is arguably a precondition for, and characteristic of, science in general. This means that reservations with regard to the very concept resilience, in policies and models, need to be taken seriously. Research that constantly analyses the dominant and new - and often, implicit - conceptions of resilience must thus be stimulated even if it does not seem to serve practical purposes. Critical resilience research thus also includes the integration of reflexivity in transdisciplinary research, which involves "a reflexive questioning of values, background assumptions and normative orientations" (Popa et al., 2015, p. 46) of various approaches to resilience. Critical resilience research is expected to pay attention to diverse conceptions of resilience and also to address the "question of outcomes and who gets to define them as resilient or otherwise", "the potential exclusions in determining system 'boundaries", and "the question of the political - resilience from what, to what, and who gets to decide?" (Porter and Davoudi, 2012, p. 331). Such critical resilience research can accompany other resilience research, thereby preventing science from serving ideological goals.

A third research avenue, somewhat related to the second theme, consists in the contextualization of resilience research and discourse, that is, in embedding them in their political and cultural context. By understanding the bigger picture in which both the ecological crisis and the responses to it arise, it may be possible to govern resilience research towards sustainability and justice and to identify the factors - which may be institutional, cultural, or political - that stimulate or deter such changes (see Bahadur and Tanner, 2014). In a systems thinking language, such research can identify the various agents that maintain or disrupt the system. An example of disruptive forces may then be environmental movements that are able to develop a leverage required to transform established systems (such as energy systems) and their governance arrangements. Agents that maintain the system, on the other hand, include those who hold power, thanks to such arrangements, and typically use tactics of repression and criminalization, particularly in the extractive sectors of the Global South (Szablowski and Campbell, 2019). Research focusing on the different fields of forces in various political contexts may discover how differences in system adaptation and reconfiguration relate to particular administrative capacities and governance arrangements (see Blühdorn, 2013; Fischer, 2017; Davoudi, 2018; Köhler et al., 2019; Mummery and
Mummery, 2019). It can also generate insights into the (possible) connection between particular resilience policies and models, on the one hand, and new forms of power inequalities, polarization, injustice, and democratic deficits, on the other hand. Bierbaum and Stults (2013, p. 18) point to the "growing recognition of the need for a new model of deep and long-term stakeholder engagement". Such a model ensures that all (local) stakeholders are involved in determining a "vision of resilience, impediments to achieving that vision, and contextually relevant actions for achieving that vision" (Bierbaum and Stults, 2013, p. 30). It can safeguard both the effectiveness and equitability of solutions.

A fourth promising topic for future resilience research is the interplay between adaptive resilience and transformative resilience and transformational adaptation (Clément and Rivera, 2017). The focus can be on the ways in which transformational adaptation manifests itself, how multiple adaptations may lead to transformational adaptation, and the threshold that needs to be surpassed for adaptation to be considered transformational (Grove and Chandler, 2017; Glaser et al., 2018). The notion of "tentative governance" appears particularly relevant in the context of transformational politics, when it comes to phasing out systems and weakening adaptive resilience. Tentative governance is marked by interventions that are designed as preliminary rather than as persistent, for purposes of probing and learning rather than for stipulating definite targets or fixating existing systems and their underlying assumptions (Kuhlmann et al., 2019). It is likely that stakeholder engagement (including resistance) in transformational politics and tentative governance varies, and manifests itself differently, across different policy fields. For instance, the sustainable energy transformation may include multi-layer governance challenges, many pro-active stakeholders, and new investment opportunities and job opportunities. In contrast with the sustainable energy transformation, sea-level rise and the disruption and relocation of coastal cities may trigger a more limited transformative politics, despite inevitable transformation of systems due to shocks and disturbances (metamorphosis). Yet, in the coming decade, transformational politics and tentative governance - including anthropogenic topics like population displacement, privatization of climate adaptation, conflict surrounding scarce resources (like water resources), intergenerational environmental conflict, and the shutting down of old infrastructures that are too costly to maintain - become more urgent research topics.

The fifth research theme concerns the relationship between the phasing out of unsustainable systems and societal transformations. What are the implications of the disintegration of old systems for societies, that is, for their cultures, collective identities, traditions, economies, political-administrative power constellations, class structures, etc.? Which societal transformations promote such disintegration? Research topics encompass the governing and accelerating of the decline of existing systems and their adaptive cycles (Stegmaier et 
al., 2014, 2020; Hoffmann et al., 2017); the particular circumstances in which accelerations can manifest themselves; the identification of, and coping with, uncertainties in processes of adaptation and transformation and transformational adaptation; and the construction of new incentive structures, for accelerating sustainable transformation (see Clément and Rivera, 2017; Warmink et al., 2017; Köhler et al., 2019). This branch of discontinuation research assumes that technologies influence socio-ecological systems. Some technologies threaten resilience to climate change, while others enhance it (Smith and Stirling, 2010), which brings us to another related research topic, namely the implications of the so-called "AI revolution" and the (top-down and politically steered) making of the alleged "age of artificial intelligence" for resilience research and SES (Berendt, 2019).

Given worldwide investments in AI technologies and topdown AI strategies that global governance actors and national governments have recently published (Ossewaarde and Gülenç, 2020), AI will most plausibly become a major force that shapes or undermines resilience to climate change. New interplays between automation, (un)sustainability, and adapting and transforming systems trigger new questions for future resilience research (see Köhler et al., 2019). Hoefsloot et al. (2019) have expressed the concern that the total and unconditional reliance on the data generated by AI technology may lead to a flawed prediction of climate disasters. For instance, the coverage of climate disasters - satellite data, drone data, sensor data, social media data, volunteer geographic information (VGI) data, among others - may be incomplete and leave out certain geographical areas and even certain social groups (Hoefsloot et al., 2019). Other sources of information are necessary to ensure more accurate measurements (and predictions), complement data gaps, and identify the needs of local communities (Bierbaum and Stults, 2013; Pfeffer and Georgiadou, 2019). A recent example of the integration of different sources of knowledge is the resilient settlement program led by UN HABITAT, which brought together a multitude of actors (policy, private, academic, community organizations) and data and algorithms and local knowledge to identify settlements at risks (UNHabitat, 2019). This example illustrates the importance of embedding AI technologies in particular contexts so that the needs of particular communities, for instance, are served, and fairness and transparency are safeguarded. Resilience research and models must therefore include an evaluation of AI technologies. How have data been acquired and by whom? What are the implications of particular AI technologies for the SES in question? Which new power relations are established through the reliance on AI technologies? Which stakeholders are being included and which ones are being excluded during the whole process, beginning with the problem definition and extending to the formulation of solutions that involve an intensive application of AI? (Rajan and Saffiotti, 2017; Taddeo and Floridi, 2018; Khakurel et al., 2018; Vahedifard et al., 2019; Miller, 2019; Saravi et al., 2019).
A sixth theme for future resilience research concerns the role of environmental, energy, and climate justice in theorizing, modeling, interpreting, and explaining resilience to climate change (see Skillington, 2015; Fazey et al., 2018; Mummery and Mummery, 2019). What kind of research results from the integration of theories of environmental justice, energy justice, and climate justice into adaptive and transformative resilience and transformational adaptation models? Future resilience research will somehow have to confront wicked problems: given unstable political contexts, scarcity of "resources", and struggles for survival and power, how can principles of equity, fairness, and access to resources and services be secured? In the problematic context of mobilities and a political environment marked by anti-immigration policies, how can the wellbeing of migrants be ensured and, in general, human rights be safeguarded? How can the disparity and inequality in the distribution of risks, locally and globally, be tackled? Equity in this regard will mean much more than equality. Other challenges include the incorporation of cross-sectional dimensions of justice, particularly gender and ethnic relations, into climate justice (Terry, 2009) and energy justice (Feenstra and Özerol, 2018) frameworks. And in the Global South, addressing issues of corruption, violence, poverty, and lack of access to resources (and violent battles for resources) and services (like education and sanitation) may have a higher priority than global environmental considerations (Köhler et al., 2019).

\section{Conclusion}

In the social sciences, resilience to climate change is a concept that is incorporated in different theoretical approaches that are linked to contrasting scientific approaches. Holling originally reinterpreted and incorporated the notion of resilience in his SES approach, which was then picked up by naturalist scientists and embedded in cybernetic complexity theory, for instance. The complexity theory was for a very long time the preferred approach to resilience to climate change in the social sciences. This situation changed as resilience increasingly became the theme of political discourses and policies a decade ago, especially in the wake of socio-ecological catastrophes, financial crises, and pandemics. The instrumentalization and decontextualization of resilience by local and global governance actors invited the critical response of scholars who often had recourse to constructivist approaches. The diversification of resilience research and expansion of the social scientific jargon resulted from this development. The question of whether resilience should operate as a unifying paradigm is not yet settled. However, it may well facilitate interdisciplinary dialogue and even transdisciplinarity. Such cooperation or dialogue is arguably necessary given the extremely complex nature of our socio-ecological predicaments. New light may be shed on how new political-administrative institutions (including pa- 
narchical self-organization) and practices can respond in legitimate ways (taking justice and vulnerability considerations into account) to the challenges of addressing climate change impacts, in different ecological, political, and technological contexts (see Johnsson et al., 2018).

The six themes for future resilience research that we have identified combine naturalist and constructivist insights and approaches so that human agency, reflexivity, and considerations of justice and equity are incorporated into research that predominantly involves systems thinking. In fact, further cooperation is the first identified research theme. Interdisciplinary and multidisciplinarity between naturalist and constructivist approaches and the many varieties of these approaches can prove to be challenging, not only because of clashing methodologies and conceptual frameworks, but also because of institutional factors. Yet, there have been attempts to reduce the gap between these approaches, without eliminating a fruitful tension. The second research area could be called critical resilience research. It includes questioning the very concept of resilience and proposing alternatives or supplementary concepts. Such critical resilience research will most probably be a complement to, or necessary component of, other resilience research. The third theme consists in the contextualization of resilience research, which serves the multiple purposes of effectiveness (of measures), sustainability, and justice. The interaction as well as the blurry line between adaption (adaptive resilience) and transformation (transformative resilience) is the fourth research area. Related to the latter topic is research focusing on the twoway relationship between the phasing out of unsustainable systems and societal transformations. Given the increasing incorporation of AI technologies in resilience research and policies, a fifth research topic pertains to the implications of AI technologies for societies, and more specifically for sustainability and justice. The final theme is the integration of various forms of justice (such as inter-racial) and theories of justice into resilience research. We believe that the multifariousness of climate change resilience research is inevitable and also desirable given the complexity of the issues under consideration. Whether such diversity is maintained will depend on external factors, such as the preferences of research institutes (and governments) and the availability of funding for all lines of research.

Data availability. No data sets were used in this article.

Author contributions. RO prepared the paper with contributions from all co-authors. RO and BB designed the study. RO carried out the review and constructed the research agenda, with contributions from TF, YG, AH, GÖ, KP, PS, RT, MV, JW, and BS. RO drafted the article. All the co-authors contributed to interpretation of the results, provided suggestions, and contributed to further reviewing the paper.
Competing interests. The authors declare that they have no conflict of interest.

Acknowledgements. We would like to thank the reviewers for their valuable comments on a previous version of this article and the editorial team for their support.

Review statement. This paper was edited by Animesh Gain and reviewed by Md. Shibly Sadik, Sate Ahmad, and two anonymous referees.

\section{References}

Acosta, C., Ortega, M., Bunsen, T., Koirala, B. P., and Ghorbani, A.: Facilitating energy transition through energy commons: an application of socio-ecological systems framework for integrated community energy systems, Sustainability, 10, 366, https://doi.org/10.3390/su10020366, 2018.

Adger, W. N., Brown, K., Nelson, D. R., Berkes, F., Eakin, H., Folke, C., Galvin, K., Gunderson, L., Goulden, M., O’Brien, M., Ruitenbeek, J., and Tompkins, E. L.: Resilience implications of policy responses to climate change, WIRE's Clim. Change, 2, 757-766, 2011.

Aiken, S. F.: Pragmatism, Naturalism, and Phenomenology, Human Stud., 29, 317-340, 2006.

Alexander, D. E.: Resilience and disaster risk reduction: an etymological journey, Nat. Hazards Earth Syst. Sci., 13, 2707-2716, https://doi.org/10.5194/nhess-13-2707-2013, 2013.

Alexander, S. and Yacoumis, P.: Degrowth, energy descent, and "low-tech" living: Potential pathways for increased resilience in times of crisis, J. Clean. Product., 197, 1840-1848, 2018.

Allen, C. R., Angeler, D. G., Germestani, A. S., Gunderson, L. H., and Holling, C. S.: Panarchy: Theory and Application, Ecosystems, 17, 578-589, 2014.

Alova, G.: A global analysis of the progress and failure of electric utilities to adapt their portfolios of power-generation assets to the energy transition, Nat. Energy, 5, 1-8, 2020.

Anderson, B.: What kind of thing is resilience?", Politics, 35, 6066, 2015 .

Andler, D.: Is social constructivism soluble in critical naturalism?, in: New Directions in the Philosophy of Science. The Philosophy of Science in a European Perspective, edited by: Galavotti, M. Dieks, D., Gonzalez, W., Hartmann, S., Uebel, T., and Weber, M., Springer, London, 2014.

Bahadur, A. and Tanner, T.: Transformational resilience thinking: putting people, power and politics at the heart of urban climate resilience, Environ. Urban., 26, 200-214, 2014.

Beck, U.: Emancipatory catastrophism: What does it mean to climate change and risk society?, Curr. Sociol., 63, 75-88, 2015.

Belkhir, J. A. and Charlemaine, C.: Race, Gender and Class Lessons from Hurricane Katrina, Race Gender Class, 14, 120-152, 2007.

Béné, C., Mehta, L., McGranahan, G., Cannon, T., Gupte, J., and Tanner, T.: Resilience as a policy narrative: potentials and limits in the context of urban planning, Clim. Dev., 10, 116-133, 2018.

Berbés-Blázquez, M., Mitchell, C. L., Burch, S. L., and Wandel, J.: Understanding climate change and resilience: assessing strengths 
and opportunities for adaptation in the Global South, Climatic Change, 141, 227-241, 2017.

Berendt, B.: AI for the common good?! Pitfalls, challenges, and ethics pen-testing, Paladyn, 10, 44-65, 2019.

Bergmann, Z. and Ossewaarde, R.: Youth climate activists meet environmental governance: Ageist depictions of the FFF movement and Greta Thunberg in German newspaper coverage, J. Multicult. Discours., 15, 267-290, https://doi.org/10.1080/17447143.2020.1745211, 2020.

Bergström, J.: An archaeology of societal resilience, Safe. Sci., 110, 32-38, 2018.

Berkes, F. and Ross, H.: Panarchy and community resilience: Sustainability science and policy implications", Environ. Sci. Policy, 61, 185-193, 2016.

Bierbaum, R. and Stults, M.: Adaptation to climate change: Context matters, Michig. J. Sustainabil., 1, 15-30, 2013.

Blühdorn, I.: The governance of unsustainability: ecology and democracy after the post-democratic turn, Environ. Polit., 22, 16-36, 2013.

Boas, I. and Rothe, D.: From conflict to resilience? Explaining recent changes in climate security discourse and practice, Environ. Polit., 25, 613-632, 2016.

Boyer, J.: Toward an Evolutionary and Sustainability Perspective of the Innovation Ecosystem: Revisiting the Panarchy Model, Sustainability, 12, 3232, https://doi.org/10.3390/su12083232, 2020.

Borsje, B. W., van Wesenbeeck, B., Dekker, F., Paalvast, P., Bouma, T. J., and De Vries, M. B.: How ecological engineering can serve in coastal protection - a review, Ecol. Eng., 37, 113-122, 2011.

Bourbeau, P.: Resilience and international politics: Premises, debates, agenda, Int. Stud. Rev., 17, 374-395, 2015.

Bourbeau, P. and Ryan, C.: Resilience, resistance, infrapolitics and enmeshment, Eur. J. Int. Relat., 24, 221-239, 2018.

Boyd, E., Nykvist, B., Borgström, S., and Stacewicz, I. A.: Anticipatory governance for social-ecological resilience, Ambio, 44, 149-161, 2015.

Braun, B. P.: A new urban dispositif? Governing life in an age of climate change, Environ. Plan. D, 32, 49-64, 2014.

Buschmann, P. and Oels, A.: The overlooked role of discourse in breaking carbon lock-in: The case of the German energy transition, Wiley Interdisciplin. Rev.: Clim. Change, 10, 1-14, 2019.

Carolan, M. S.: Realism without reductionism: toward an ecologically embedded sociology, Human Ecol. Rev., 12, 1-20, 2005.

Chandler, D.: Beyond neoliberalism: resilience, the new art of governing complexity, Resilience, 1, 47-63, 2014.

Clément, V. and Rivera, J.: From adaptation to transformation: An extended research agenda for organizational resilience to adversity in the natural environment, Organiz. Environ., 30, 346-365, 2017.

Code, L.: Ecological naturalism: Epistemic responsibility and the politics of knowledge, Dialog. Universal., 15, 87-101, 2005.

Cole, A.: All of us are vulnerable, but some are more vulnerable than others: The political ambiguity of vulnerability studies, an ambivalent critique, Crit. Horizon., 17, 260-277, 2016.

Conte, R. and Paolucci, M.: On agent-based modeling and computational social science, Front. Psychol., 5, 668, https://doi.org/10.3389/fpsyg.2014.00668, 2014.

Cook, J., Oreskes, N., Doran, P. T., Anderegg, W. R., Verheggen, B., Maibach, E. W., and Nuccitelli, D.: Consensus on consensus: a synthesis of consensus estimates on human- caused global warming, Environ. Res. Lett., 11, 048002, https://doi.org/10.1088/1748-9326/11/4/048002, 2016.

Cote, M. and Nightingale, A. J.: Resilience thinking meets social theory: Situating social change in socio-ecological systems (SES) research, Prog. Human Geogr., 36, 475-489, 2012.

Dahlberg, R.: Resilience and complexity: Conjoining the discourses of two contested concepts, Cult. Unbound, 7, 541-557, 2015.

Dahlberg, R., Johannessen-Henry, C. T., Raju, E., and Tulsiani, S.: Resilience in disaster research: Three versions, Civ. Eng. Environ. Syst., 32, 44-54, 2015.

Davoudi, S.: Just resilience, City Commun., 17, 3-7, 2018.

Derickson, K. D.: Resilience is not enough, City, 20, 161-166, 2016.

Dijkman, J., Klomp, R., and Villars, M.: Flood management strategies for the Rivers Rhine and Meuse in The Netherlands, IAHS Publications - Series of Proceedings and Reports - Intern Assoc Hydrological Sciences, 239, 371-382, 1997.

Douglas, M. and Wildavsky, A.: Risk and Culture. An Essay on the Selection of Technological and Environmental Dangers, University of California Press, Berkeley, 1983.

Dryzek, J. S. and Pickering, J.: The Politics of the Anthropocene, Oxford University Press, Oxford, 2019.

Duit, A.: Resilience thinking: Lessons for public administration, Publ. Administrat., 94, 364-380, 2016.

Estêvão, P., Calado, A., and Capucha, L.: Resilience: Moving from a "heroic" notion to a sociological concept, Sociologia, Problemas E Práticas, 85, 9-25, 2017.

Evans, B. and Reid, J.: Dangerously exposed: the life and death of the resilient subject, Resilience, 1, 83-98, 2013.

Fainstein, S.: Resilience and justice, Int. J. Urban Reg. Res., 39, 157-167, 2014.

Farmer, J. D. and Foley, D.: The economy needs agent-based modelling, Nature, 460, 685-686, 2009.

Fazey, I., Moug, P., Allen, S., Beckmann, K., Blackwood, D., Bonaventura, M., Burnett, K., Danson, M., Falconer, R., Gagnon, A. S., Harkness, R., Hodgson, A., Holm, L., Irvine, K. N., Low, R., Lyon, C., Moss, A., Moran, C., Naylor, L., O’Brien, K., Russell, S., Skerratt, S., Rao-Williams, J., and Wolstenholme, R.: Transformation in a changing climate: a research agenda, Clim. Dev., 10, 197-217, 2018.

Feenstra, M. and Özerol, G.: Using energy justice as a search light for gender and energy policy research: a systematic review, in: 12th ECPR General Conference, August 2018, Hamburg, Germany, 2018.

Filatova, T., Polhill, J. G., and Van Ewijk, S.: Regime shifts in coupled socio-environmental systems: Review of modelling challenges and approaches, Environ. Model. Softw., 75, 333-347, 2016.

Fischer, F.: Climate crisis and the democratic prospect: participatory governance in sustainable communities, Oxford University Press, Oxford, 2017.

Floridi, L.: A plea for non-naturalism as constructionism, Minds Mach., 27, 269-285, 2017.

Folke, C.: Resilience: The emergence of a perspective for socialecological systems analyses, Global Environ. Change, 16, 253267, 2006

Gallopin, G. C.: Linkages between vulnerability, resilience, and adaptive capacity, Global Environ. Change, 16, 293-303, 2006. 
Geels, F. W.: Regime resistance against low-carbon transitions: introducing politics and power into the multi-level perspective, Theor. Cult. Soc., 31, 21-40, 2014.

Gençsü, I., Whitley, S., Trilling, M., van der Burg, L., McLynn, M., and Worrall, L.: Phasing out public financial flows to fossil fuel production in Europe, Clim. Policy, 20, 1010-1023, 2020.

Glaser, M., Plass-Johnson, J. G., Ferse, S. C. A., Neil, M., Satari, D. Y., Teichberg, M., and Reuter, H.: Breaking resilience for a sustainable future: Thoughts for the Anthropocene, Front. Mar. Sci., 5, 34, https://doi.org/10.3389/fmars.2018.00034, 2018.

Groß, M. and Stauffacher, M.: Transdisciplinary environmental science: problem-oriented projects and strategic research programs, Interdisciplin. Sci. Rev., 39, 299-306, 2014.

Grove, K. and Chandler, D.: Introduction: Resilience and the Anthropocene: The stakes of "renaturalising" politics", Resilience, 5, 79-91, 2017.

Haasnoot, M., Kwakkel, J. H., Walker, W. E., and Ter Maat, J.: Dynamic adaptive policy pathways: A method for crafting robust decisions for a deeply uncertain world, Global Environ. Change, 23, 485-498, 2013.

Hamers, T., Kamstra, J. J., Van Gils, J. Kotte-Albertus, M. C., and Van Hattum, G. M.: The influence of extreme river discharge conditions on the quality of suspended particulate matter in Rivers Meuse and Rhine (The Netherlands), Environm. Res. A, 143, 241-255, 2015.

Hawes, C. and Reed, C.: Theoretical steps towards modelling resilience in complex systems, in: Computational Science and Its Applications, ICCSA 2006, Lecture Notes in Computer Science, vol. 3980, edited by: Gavrilova, M., Springer, Berlin, 2006.

Heffron, R. J. and McCauley, D.: The concept of energy justice across the disciplines, Energy Policy, 105, 658-667, 2017.

Henkel, K. E., Dovidio, J. F., and Gaertner, S. L.: Institutional discrimination, individual racism, and Hurricane Katrina, Anal. Social Issue. Publ. Policy, 6, 99-124, 2006.

Hoefsloot, F. I., Pfeffer, K., and Richter, C.: People and places uncounted: Legibility in the water infrastructure of Lima, Peru, Paper presented at City Futures 2019, Dublin, Ireland, 1-17, 2018.

Hoekstra, A. Y., Bredenhoff-Bijlsma, R., and Krol, M. S.: The control versus resilience rationale for managing systems under uncertainty, Environ. Res. Lett., 13, 103002, https://doi.org/10.1088/1748-9326/aadf95, 2018.

Hoffmann, S., Weyer, J., and Longen, J.: Discontinuation of the automobility regime. An integrated approach to multi-level governance, Transport. Res. A, 103, 391-408, 2017.

Holling, C. S.: Resilience and stability of ecological systems, Annu. Rev. Ecol. System., 4, 1-23, 1973.

Holling, C. S.: Understanding the complexity of economic, ecological, and social systems, Ecosystems, 4, 390-405, 2001.

Howell, A.: Resilience as enhancement: Governmentality and political economy beyond "responsibilisation", Politics, 35, 67-71, 2015.

Huang, H., Boranbay-Akan, S., and Huang, L.: Media, protest diffusion, and authoritarian resilience, Polit. Sci. Res. Meth., 7, 23 42, 2016.

Hughes, S.: The politics of urban climate change policy: Towards a research agenda, Urban Affair. Rev., 53, 362-380, 2017.

Indirli, M.: An historical flight and some open questions towards a pluralistic but holistic view of resilience, Geogr. Anthrop., 2, 194-248, 2019.
Jenkins, K., McCauley, D., Heffron, R., Stephan, H., and Rehner, R.: Energy justice: A conceptual review, Energ. Res. Social Sci., 11, 174-182, 2016.

Jesse, B.-J., Heinrichs, H. U., and Kuchshinrichs, W.: Adapting the theory of resilience to energy systems: a review and outlook, Energ. Sustain. Soc., 9, 27, https://doi.org/10.1186/s13705-0190210-7, 2019.

Johnson, J. L., Zanotti, L., Ma, Z., Yu, D. J., Johnson, D. R., Kirkham, A., and Carothers, C.: Interplays of Sustainability, Resilience, Adaptation and Transformation, in: Handbook of Sustainability and Social Science Research, World Sustainability Series, edited by: Leal Filho, W., Marans, R., and Callewaert, J., Springer, Cham, 2018.

Juncos, A. E.: Resilience as the new EU foreign policy paradigm: a pragmatist turn?, Europ. Secur., 26, 1-18, 2017.

Juncos, A. E.: Resilience in peacebuilding: Contesting uncertainty, ambiguity, and complexity, Contemp. Secur. Policy, 39, 559574, 2018.

Katomero, J. and Georgiadou, Y.: The elephant in the room: Informality in Tanzania's rural waterscape, ISPRS Int. J. Geo-Inform., 7, 437, https://doi.org/10.3390/ijgi7110437, 2018.

Kelman, I.: Disaster by choice: how our actions turn natural hazards into catastrophes, Oxford University Press, Oxford, 2020.

Khakurel, J., Penzenstadler, B., Porras, J., Knutas, A., and Zhang, W.: The rise of artificial intelligence under the lens of sustainability, Technologies, 6, 100, https://doi.org/10.3390/technologies6040100, 2018.

Köhler, J., Geels, F. W., Kernc, F., Markard, J., Onsongo, E., Wieczorek, A., Alkemade, F., Avelino, F., Bergek, A., Boons, F., Fünfschilling, L., Hess, D., Holtz, G., Hyysalok, S., Jenkins, K., Kivimaa, P., Martiskainen, M., McMeekin, A., Muhlemeier, M. S., Nykvist, B., Pel, B., Raven, R., Rohracher, H., Sandén, B., Schot, J., Sovacool, B., Turnheim, B., Welch, D., and Wells, P.: An agenda for sustainability transitions research: State of the art and future directions, Environ. Innov. Soc. Transit., 31, 1-32, 2019.

Kolers, A.: Resilience as a political ideal, Eth. Policy Environ., 19, 91-107, 2016.

Ksenia, C., Lizarralde, G., Dainty, A., and Bosher, L.: Unpacking resilience policy discourse, Cities, 58, 70-79, 2016.

Kuhlmann, S., Stegmaier, P., and Konrad, K.: The tentative governance of emerging science and technology - A conceptual introduction, Res. Policy, 48, 1091-1097, 2019.

Kythreotis, A. P. and Bristow, G. I.: The "resilience trap": exploring the practical utility of resilience for climate change adaptation in UK city-regions, Reg. Stud., 51, 1530-1541, 2017.

Lockie, S.: Beyond resilience and systems theory: reclaiming justice in sustainability discourse, Environ. Sociol., 2, 115-117, 2016.

Lyster, R.: Climate justice, adaptation and the Paris Agreement: A recipe for disasters?, Environ. Polit., 26, 438-458, 2017.

Martin, R. and Schlüter, M.: Combining system dynamics and agent-based modeling to analyze social-ecological interactions - an example from modeling restoration of a shallow lake, Front Environ. Sci., 3, 66, https://doi.org/10.3389/fenvs.2015.00066, 2015.

McGreavy, B.: Resilience as discourse, Environ. Commun., 10, 104-121, 2016. 
Miller, F., Osbahr, H., Boyd, E., Thomalla, F., Bharwani, S., Ziervogel, G., Walker, B., Birkmann, J., Van der Leeuw, S., Rockström, J., Hinkel, J., Downing, T., Folke, C., and Nelson, D.: Resilience and vulnerability: Complementary or conflicting concepts?, Ecol. Soc., 15, 11, 2010.

Miller, T.: Explanation in artificial intelligence: Insights from the social sciences, Artific. Intel., 267, 1-38, 2019.

Mirchandani, C.: Resilience Modeling in Complex Systems, Proced. Comput. Sci., 168, 232-240, 2020.

Mooney, H. A., Duraiappah, A., and Larigauderie, A.: Evolution of natural and social science interactions in global change research programs, P. Natl. Acad. Sci. USA, 110, 3665-3672, 2013.

Mummery, J. and Mummery, J.: Transformative climate change adaptation: Bridging existing approaches with post-foundational insights on justice, Local Environ., 24, 919-930, 2019.

Olsson, L.: Why resilience is unappealing to social science: Theoretical and empirical investigations of the scientific use of resilience, Sci. Adv., 1, 4, https://doi.org/10.1126/sciadv.1400217, 2015.

Ossewaarde, M. and Gülenç, E.: National varieties of AI discourses: Myth, utopianism and solutionism in West European policy expectations, Computer, 53, 53-61, 2020.

Ostrom, E.: A diagnostic approach for going beyond panaceas, P. Natl. Acad. Sci. USA, 104, 15181-15187, 2007.

Patriarca, R., Bergström, J., Di Gravio, G., and Costantino, F.: Resilience engineering: Current status of the research and future challenges, Safe. Sci., 102, 79-100, 2018.

Pelling, M., O'Brien, K., and Matyas, D.: Adaptation and transformation, Climatic Change, 133, 113-127, 2015.

Pfeffer, K. and Georgiadou, Y.: Global ambitions, local contexts: Alternative ways of knowing the world, ISPRS Int. J. GeoInform., 8, 516, https://doi.org/10.3390/ijgi8110516, 2019.

Pizzo, B.: Problematizing resilience: Implications for planning theory and practice, Cities, 43, 133-140, 2015.

Pohl, C.: How to bridge between natural and social sciences? An analysis of three approaches to transdisciplinary from the Swiss and German field of environmental research, Nat. Sci. Soc., 9, 37-46, 2001.

Pompe, J. J. and Rinehart, J. R.: Environmental conflict: In search of common ground, State University of New York Press, Albany, NY, 2002.

Popa, F., Guillermin, M., and Dedeurwaerdere, T.: A pragmatist approach to transdisciplinarity in sustainability research: From complex systems theory to reflexive science, Futures, 65, 45-56, 2015.

Porter, L. and Davoudi, S.: The politics of resilience for planning: A cautionary note, Plan. Theory Pract., 13, 329-333, 2012.

Proctor, J. D.: Expanding the scope of science and ethics, Ann. Assoc. Am. Geogr., 88, 290-296, 1998a.

Proctor, J. D.: The social construction of nature: Relativist accusations, pragmatist and critical realist responses, Ann. Assoc. Am. Geogr., 88, 352-376, 1998b.

Pumpuni-Lenss, G., Blackburn, T., and Garstenauer, A.: Resilience in complex systems: An agent-based approach, Syst. Eng., 20, 158-172, 2017.

Rajan, A. and Saffiotti, A.: Towards a science of integrated AI and robotics, Artific. Intel., 247, 1-9, 2017.
Redman, C. L.: Should sustainability and resilience be combined or remain distinct pursuits?, Ecol. Soc., 19, 37, https://doi.org/10.5751/ES-06390-190237, 2014.

Ribault, T.: Resilience in Fukushima: Contribution to a political economy of consent, Alternatives, 44, 94-118, 2019.

Rothe, D.: Gendering resilience: Myths and stereotypes in the discourse on climate-induced migration, Global Policy, 8, 40-46, 2017.

Saravi, S., Kalawsky, R., Joannou, D., Rivas Casado, M., Fu, G., and Meng, F.: Use of artificial intelligence to improve resilience and preparedness against adverse flood events, Water, 11, 973 , https://doi.org/10.3390/w11050973, 2019.

Schilling, T., Wyss, R., and Binder, C. R.: The resilience of sustainability transitions, Sustainability, 10, 4593, https://doi.org/10.3390/su10124593, 2018.

Schlosberg, D., Collins, L. B., and Niemeyer, S.: Adaptation policy and community discourse: risk, vulnerability, and just transformation, Environ. Polit., 26, 413-437, 2017.

Schwartz, S.: Resilience in psychology: A critical analysis of the concept, Theory and Psychology, 28, 528-541, 2018.

Simpson, A.: Challenging inequality and injustice: A critical approach to energy security, in: Environmental Security: Approaches and Issues, edited by: Floyd, R. and Matthew, R. A., Routledge, London, 248-263, 2013.

Sjöstedt, M.: Resilience revisited: Taking institutional theory seriously, Ecol. Soc., 20, 23, https://doi.org/10.5751/ES-08034200423, 2015.

Skillington, T.: Climate justice without freedom: Assessing legal and political responses to climate change and forced migration, Eur. J. Social Theory, 18, 288-307, 2015.

Smit, M. J., Goosen, H., and Hulsbergen, C. H.: Resilience and vulnerability: Coastal dynamics or Dutch dikes?, Geogr. J., 164, 259-268, 1998.

Smith, A. and Stirling, A.: The politics of social-ecological resilience and sustainable socio-technical transitions, Ecol. Soc., $15,11,2010$.

Stegemann, L. and Ossewaarde, M.: A sustainable myth: A neoGramscian perspective on the populist and post-truth tendencies of the European green growth discourse, Energ. Res. Social Sci., 43, 25-32, 2018.

Stegmaier, P., Kuhlmann, S., and Visser, V. R.: The discontinuation of socio-technical systems as governance problem, in: Governance of Systems Change, edited by: Borrás, S. and Edler, J., Edward Elgar, Cheltenham, 111-131, 2014.

Stegmaier, P., Visser, V. R., and Kuhlmann, S.: The incandescent light bulb phase-out: Exploring patterns of framing the governance of discontinuing a socio-technical regime, in review, 2020.

Sun, L., Stojadinovic, B., and Sansavini, G.: Agent-based recovery model for seismic resilience evaluation of electrified communities, Risk Anal., 39, 1597-1614, 2019.

Szablowski, D. and Campbell, B.: Struggles over extractive governance: Power, discourse, violence, and legality, Extract. Indust. Soc., 6, 635-641, 2019.

Taddeo, M. and Floridi, L.: How AI can be a force for good, Science, 361, 751-752, 2018.

Terry, G.: No climate justice without gender justice: an overview of the issues, Gender Dev., 17, 5-18, 2009.

Thorén, H.: Resilience as a unifying concept, Int. Stud. Philos. Sci., 28, 303-324, 2014. 
Tierney, K.: Resilience and the neoliberal project: Discourses, critiques, practices - And Katrina, Am. Behav. Sci., 59, 1327-1342, 2015.

UN-Habitat: Un-habitat unveils new chinese partnership to explore the use of artificial intelligence in cities, available at: https://unhabitat.org/un-habitat-unveils-new-chinesepartnership-to-explore-the-use (last access: 8 February 2021), 2019.

Vahedifard, F., Ermagun, A., Mortezaei, K., and AghaKouchak, A.: Integrated data could augment resilience, Science, 363, 6423, https://doi.org/10.1126/science.aaw2236, 2019.

VanderPlaat, M.: Activating the sociological imagination to explore the boundaries of resilience research and practice, School Psychol. Int., 37, 189-203, 2016.

Walker, J. and Cooper, M.: Genealogies of resilience: From systems ecology to the political economy of crisis adaptation, Secur. Dialog., 42, 143-160, 2011.

Walsh-Dilley, M. and Wolford, W.: (Un)Defining resilience: Subjective understandings of "resilience" from the field, Resilience, 3, 173-182, 2015.

Ward, P. J., Aerts, J. C. J. H., De Keizer, O., and Poussin, J. K.: Adaptation to Meuse flood risk, Knowledge for Climate Report, KfC 93/2013, available at: https://edepot.wur.nl/254248 (last access: 8 February 2021), 2013.
Warmink, J. J., Brugnach, M., Vinke-de Kruijf, J., Schielen, R. M. J., and Augustijn, D. C. M.: Coping with uncertainty in river management: Challenges and ways forward, Water Resour. Manage., 31, 4587-4600, 2017.

Weichselgartner, J. and Kelman, I.: Geographies of resilience: Challenges and opportunities of a descriptive concept, Prog. Human Geogr., 39, 3, 249-267, 2015.

Wessel, R. A.: Cybersecurity in the European Union: Resilience through regulation, in: Routledge Handbook of EU Security Law and Policy, edited by: Conde Pérez, E., Yaneva, Z., and Scopelliti, M., Routledge, London, 283-300, 2019.

Wiese, F.: Resilience thinking as an interdisciplinary guiding principle for energy system transitions, Resources, 5, 30, https://doi.org/10.3390/resources5040030, 2016.

Wilson, E. O.: Consilience: The unity of knowledge, Vintage, New York, 1998.

Yanarella, E. J. and Levine, R. S.: From sustainability to resilience: Advance or retreat?, Sustainability, 7, 197-208, 2014.

Ziervogel, G., Cowen, A., and Ziniades, J.: Moving from adaptive to transformative capacity: Building foundations for inclusive, thriving, and regenerative urban settlements, Sustainability, 8 , 955, https://doi.org/10.3390/su8090955, 2016. 